\title{
First record of Borrelia burgdorferi B31 strain in Dermacentor nitens ticks in the northern region of Parana (Brazil)
}

\author{
Daniela Dib Gonçalves ${ }^{1}$, Teresa Carreira ${ }^{2,3}$, Mónica Nunes ${ }^{2,3}$, Aline Benitez ${ }^{1}$, \\ Fabiana Maria Ruiz Lopes-Mori ${ }^{1}$, Odilon Vidotto ${ }^{4}$, \\ Julio Cesar de Freitas ${ }^{4}$, Maria Luísa Vieira ${ }^{2,3}$ \\ ${ }^{1}$ Programa de Pós-Graduação em Ciência Animal, Departamento de Medicina Veterinária Preventiva, \\ Universidade Estadual de Londrina, PR, Brazil. \\ ${ }^{2}$ Grupo de Leptospirose e Borreliose de Lyme, Unidade de Microbiologia Médica, Instituto de Higiene e \\ Medicina Tropical, Universidade Nova de Lisboa, Lisboa, Portugal. \\ ${ }^{3}$ Centro de Recursos Microbiológicos, Faculdade de Ciências e Tecnologia, Caparica, Portugal. \\ ${ }^{4}$ Departamento de Medicina Veterinária Preventiva, Universidade Estadual de Londrina, PR, Brazil.
}

Submitted: January 18, 2012; Approved: November 13, 2012.

\begin{abstract}
The aim of this study was to investigate the presence of DNA of Borrelia burgdorferi sensu lato (s.1.) in ticks that feed on horses used for animal traction in rural Jataizinho, Parana, Brazil. Between February and June 2008, a total of 224 ticks was collected of which $75 \%$ were identified as Dermacentor nitens and $25 \%$ as Amblyomma cajenense. To amplify B. burgdorferi s.l. DNA, the intergenic space region (ISR) between the 5S ( $r r f) 23 \mathrm{~S}(r r l)$ rRNA genes was used as targets for nested-PCR. Two ticks of the D. nitens species were positive for B. burgdorferi s.l. Both species showed a fragment of $184 \mathrm{bp}$, but the sequencing revealed $99.9 \%$ homology with the B. burgdorferi sensu stricto (s.s.) strain B31. These results showed, for the first time, the presence of spirochete DNA infecting ticks that parasitize horses used for animal traction, in the rural municipality mentioned. In conclusion, this study opens up promising prospects for determining the infection rate of B. burgdorferi s.s. genospecies or other species in the equine population, as well as the impact of the infection rate on Lyme disease in the state of Parana.
\end{abstract}

Key words: ticks, Dermacentor nitens, Borrelia burgdorferi sensu lato, equine, rural area.

\section{Introduction}

Lyme borreliosis or Lyme disease is a multisystemic disorder caused by tick-transmitted spirochetes of the complex Borrelia burgdorferi s.l., which infects several species of wild and domestic animals, as well as humans. Lyme borreliosis is currently considered to be an emerging zoonosis, and it occurs in different continents, including South America. The disease may have different clinical manifestations depending of which Borrelia species is involved (Baranton et al., 2001).

The maintenance of B. burgdorferi s.l. in a particular region depends on the presence of reservoir hosts (Durden et al., 2001). Wild animals (deers, rodents, marsupials and birds) act as natural reservoirs (Soares et al., 2000). Domestic animals can become either accidental reservoirs of these spirochetes or hosts for vectors, especially in residential areas (Anderson, 1988). Humans can be accidentally infected when traveling or working in environments infested with infected ticks (Yoshinari et al., 1995).

Tick-borne diseases have arisen in South America, particularly in Colombia (Palácios et al., 1999) and Bolivia (Ciceroni et al., 1997). In Brazil, the first case of Lyme disease was found in the state of São Paulo (Yoshinari et al., 1993a). In some Brazilian states, serological surveys have reported the presence of antibodies anti-Borrelia burgdorferi s.l., which is a Lyme borreliosis simile in hu- 
mans as well as in different species of wild and domestic animals (Yoshinari et al., 1997; Fonseca et al., 2005). These previous studies suggest the presence of Lyme borreliosis in Brazil, and they show not only the importance of this disease in terms of public health but also the role of ticks as vectors in transmission of disease agents to the human to the human population. However, the causal agent of Lyme Borreliosis is unknown according to Dantas-Torres (2008).

The purpose of this study was to investigate the presence of DNA of Borrelia burgdorferi s.l. in ticks that feed on equines used as animal traction in the municipality of Jataizinho, Parana, Brazil.

\section{Material and Methods}

\section{Sample collection and taxonomic identification}

Between February and June 2008, 224 ticks were collected from equines used for animal traction, at 22 rural properties in the municipality of Jataizinho. These properties were described by INCRA (National Institute of Colonization and Agrarian Reform) as small properties with limited extension and minifundia. Jataizinho is located in the northern region of the state of Parana at the following coordinates: $56^{\circ} 14^{\prime} 15^{\prime \prime} \mathrm{S}$ and $50^{\circ} 58^{\prime} 48^{\prime \prime} \mathrm{W}$. This area is bordered by the Tibagi River with an area of $201,847 \mathrm{~km}^{2}$, $346 \mathrm{~m}$ above sea level and a wet subtropical climate. According to the official administrative data, the rural population was estimated to be 1,850 inhabitants.

At least, five ticks were removed from each equine and packed in sterile plastic bags and date and place of capture were recorded. At the laboratory, ticks were kept at $-20{ }^{\circ} \mathrm{C}$ for further taxonomic identification and molecular analysis in order to detect the presence of B. burgdorferi s.l. Identification of taxa (genus and species) was performed using dichotomous keys based on Brazilian Ixodidae fauna (Aragão et al., 1961; Barros-Battesti et al., 2006). Prior to DNA extraction, ticks were, firstly, rinsed with a solution of sodium hypochlorite followed by another washing with a solution of ethanol $70^{\circ}$ and distilled water for five minutes (Couceiro et al., 2003). Ticks were preserved in sterile tubes at $-20{ }^{\circ} \mathrm{C}$ for further molecular analysis.

\section{DNA extraction, nested PCR (Polymerase Chain Reaction)}

Genomic DNA from the ticks was extracted by alkaline hydrolysis according to previously described methodologies (Guy and Stanek, 1991; De Michelis et al., 2000).

A culture of $B$. garinii (strain $\mathrm{PBi}$ ) containing about $2 \times 10^{7}$ cells $/ \mathrm{mL}$ was used as positive control. DNA of this genospecies was extracted by the Puregene ${ }^{\mathrm{TM}}$ Gentra Cell \& Tissue Kit (Qiagen, Valencia, CA, USA) following the manufacturers protocol. DNA lysates were stored at $4{ }^{\circ} \mathrm{C}$ for immediate use or at $-20{ }^{\circ} \mathrm{C}$ for further use.

To avoid contaminations, all procedures were performed in different rooms and in sterile chambers. Amplifi- cation of B. burgdorferi s.l. DNA was performed by nested PCR targeting the 5S (rrf) 23S ( $r r l$ ) intergenic spacer region. For each nested PCR reaction, two sets of oligonucleotide sequences were used as previously described (Rijpkema et al., 1995; Kurtenbach et al., 1998; De Michelis et al., 2000; Couceiro et al., 2003) and DNA amplifications were performed in a thermocycler (MyCycler ${ }^{\mathrm{TM}}$, Bio-Rad, Hercules, CA, USA). The positive control corresponds to the $380 \mathrm{bp}$ and $230 \mathrm{bp}$ fragments obtained in the first and second amplification, respectively. To prevent false results, negative controls were incorporated into the PCR procedures. The amplicons obtained were electrophoresed with $1.5 \%$ agarose gels (Bioline, London, UK), stained with $0.5 \mathrm{mg} / \mathrm{ml}$ of ethidium bromide (Bio-Rad, Hercules, CA, USA) and visualized under UV illumination with Dolphin-1D Gel Image Analysis Software (Wealtec Corp. NV, USA). The samples that produced amplicons at approximately $230 \mathrm{bp}$ to $380 \mathrm{bp}$ were kept at $-20^{\circ} \mathrm{C}$ for further use.

PCR products were purified and directly sequenced for both strands by the Sequencing Service Macrogen, Inc. (Seoul, Korea). The primers used for DNA amplification were used for sequencing. The results obtained were compared with the Borrelia genospecies sequences, registered in GenBank database, using the BLAST sequence analysis tool (www.ncbi.nlm.nih.gov/blast/Blast).

\section{Results}

A total of 224 adult ticks was removed from equines, most of which $(n=168)$ were engorged female. Based on morphological observations, ticks were taxonomically identified as Dermacentor nitens (75.0\%) and Amblyomma cajenense $(25.0 \%)$, both genera belonging to the Ixodidae family.

The nested PCR showed Borrelia DNA in two ticks with an amplicon of $230 \mathrm{bp}$ approximately. However, considering the intensity, of the band (amplicon) in the gel only one PCR product was sequenced. The amplicon (Figure 1), corresponding to a specimen identified as Dermacentor nitens (an engorged female) and designated as Jataí 01 according to its geographic origin. DNA sequencing of the PCR (on both strands) showed a sequence with $184 \mathrm{pb}$ (Table 1) and a $99.9 \%$ similarity with the $B$. burgdorferi s.s. strain B31.

\section{Discussion}

Lyme borreliosis presents several clinical pictures, particularly, in humans (Yoshinari et al., 1993b; Galo, 2006). In Brazil, this disease was first reported in serologic studies in humans by Yoshinari et al. (1993a) and in animals by Fonseca and collaborators (Fonseca et al., 1994). So far, diverse serological cases in the human population have been reported in some states, including Rio de Janeiro, São Paulo, Mato Grosso do Sul and in the Amazonia region 


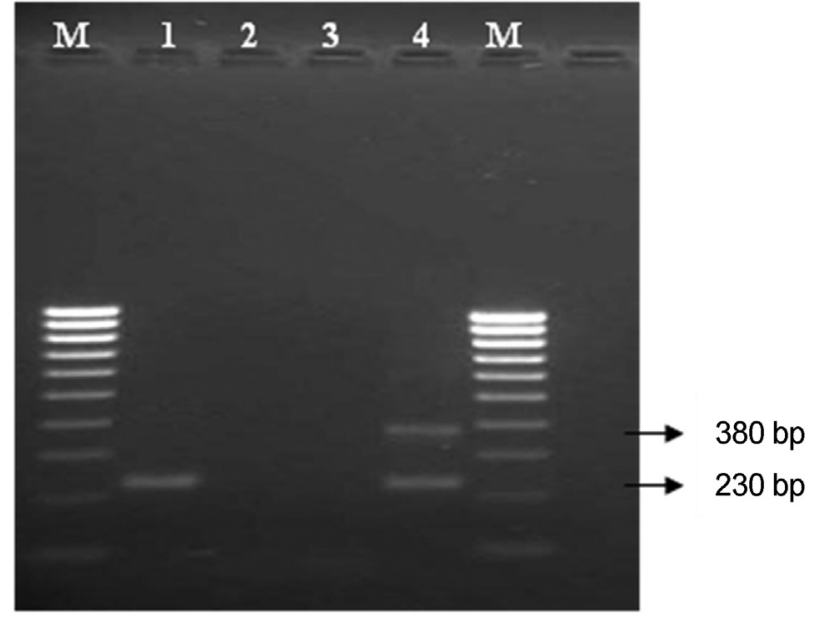

Figure 1 - DNA amplification from Dermacentor nitens by nested-PCR targeting the $B$. burgdorferi s.1. 5S (rrf) - 23S ( $r r l)$ intergenic spacer region. Lane 1: Tick sample Jataí 01- (D. nitens); lanes 2 and 3: negative controls (extraction and nested-PCR amplification); lane 4: positive control with PBi strain of $B$. garinii); M - DNA marker (100 bp).

Table 1 - Sequence identification of the B. burgdorferi s.s., B31 strain obtained from Jataí 01 tick (D. nitens), collected in the municipality of Jataizinho - Parana - Brazil.

CCCCTTGANNNNACTTACTTTGATTTTATTTTTATGTTTTTTA TATTGGTGTTTTTGAATGTGTTGTTTAAATAACATAAAAAAT AAAATATATATTGACATGTATTAAACAAAGATATATATTATT TTATGTTGTATAAATAAATTGGCAAAATAGAGATGGAAGAT AAAAATATGGTCAAAG

(Azulay et al., 1991; Talhari et al., 1992; Costa et al., 2001). All of these cases have shown significant seroprevalence rates in humans and domestic animals, suggesting that the etiologic agent of Lyme borreliosis is present in the environment (Costa et al., 2001).

According to some studies, the presence of $B$. burgdorferi s.l. has been recorded in different tick species, particularly in North America, Europe, Asia and South America (Guglielmone et al., 1987; Palácios et al., 1999; Clark et al., 2001; Gonzalo et al., 2001; Baptista et al., 2004; Gaumond et al., 2006; Hiraoka et al., 2007). In Brazil, despite the wide geographic distribution of vertebrate hosts that are susceptible to tick infestation, there are few studies concerning the transmission cycle of $B$. burgdorferi in ticks from the Ixodidae family (Martins et al., 1996). Thus, vector species for Borrelia spp in Brazil are not well known, although there is strong possibility that the species responsible for the sylvatic cycle may belong to the Ixodes genus, while the Amblyomma genus could be involved in transmission of the spirochetes to domestic animals and humans (Dantas-Torres, 2008).

In this research, the infected ticks were identified as Dermacentor nitens. This genus includes about 33 species with a worldwide distribution, except in Australia. In Eurasia, some species of $D$. marginatus and $D$. reticulates as well as of $D$. variabilis and D. andersoni from North America, infect livestock and other domestic animals. In Africa, these ticks do not play a significant role in infecting livestock (Jongejam and Uilenberg, 2008). In several Brazilian states, ticks identified as $D$. nitens have been found feeding on horses (Figueiredo et al., 1999; Martins et al., 2009) and humans (Guglielmone et al., 2006). These findings show the importance of these ticks as vectors of pathogenic agents of Lyme disease and other diseases (Fernandez-Soto et al., 2006).

In this research, the equine population was chosen due to prior knowledge that horses are the preferred hosts for ticks belonging to the Ixodes and Amblyomma genera in Brazil. Both genera are known vectors of Borrelia spirochetes. In fact, several studies carried out in animals in the states of Rio de Janeiro and Pará have reported the presence of antibodies against $B$. burgdorferi s.l., as well as the isolation of this spirochete from Boophilus microplus ticks (Salles et al., 2002; Galo, 2006; Madureira, 2007).

In this study, only two infected specimens with $B$. burgdorferi s.l. were obtained. However, this result may be underestimated due to potential inhibitors present in the blood of engorged ticks. These inhibitors included hemoglobin, which limits PCR amplification and affects the detection of specific DNA fragments (Basta and Hulínská 1999; Sparagano et al., 1999). PCR inhibitors usually affect the PCR reaction by interacting with DNA or interfering with DNA polymerase. In fact, inhibitors can survive DNA extraction/purification procedures by binding directly to single or double-stranded DNA (Bessetti, 2007). Moreover, in this study, extraction and purification of DNA from ticks were not performed with a standard kit. Instead, samples were processed with mechanical action followed by boiling the samples in an alkaline hydrolysis solution which may have enhanced their inhibitory effect.

Unlike the study by Ataliba (2006) in the state of São Paulo whose objective was to investigate Borrelia spp., in ticks parasitizing horses by nested PCR amplification for the flagelin B (flab) gene, the same technique was used in this study, but a different amplification target was employed. By using the intergenic spacer region of 5S ( $r r f$ ) -23S ( $r r l)$ rRNA genes, the detection of DNA from $B$. burgdorferi s.s., in two ticks identified as $D$. nitens (Neumann, 1889) was accomplished for the first time.

So far, the studies regarding the identification of etiologic agents for Lyme disease in Brazil have shown negative results. However, serological diagnoses with positive results have been reported in several publications, which suggest prior exposure to the agent in both domestic animals and humans. In this study, our sequencing results showed $99.9 \%$ similarity with the B. burgdorferi s.s. strain B31, which is the first report concerning the presence of this important agent for Lyme borreliosis in the state of Parana and in Brazil. 
Thus, the presence of these tick species in the equine population shows that further studies on ticks are needed to better understanding the prevalence of different tick vectors and the infection rate in domestic animals. Regarding the latter aspect, it is also important to emphasize that these equines parasitized by ticks have close contact with the human population, which justifies the development of new studies to determine its role in the transmission cycle of $B$. burgdorferi s.s. and/or other Borrelia genospecies in the peridomestic environment.

In conclusion, DNA of B. burgdorferi s.s. was detected for the first time in ticks parasitizing an equine population from the municipality of Jataizinho, Paraná state. This finding is promising for the understanding of this species and/or other genospecies of B. burgdorferi s.l. distribution in the state of Parana and other Brazilian states, pointing to the importance of the host community in the ecology of Lyme borreliosis. These methods could also be used in the future to clarify the prevalence of genospecies of Borrelia burgdorferi complex and the vectorial capacity of ticks and thus prevent the damages caused by this zoonosis in human and animal populations.

\section{Ethics Committee}

The "Zoonosis in rural residents from the municipality of Jataízinho, Parana, Brazil" project was approved on February 13, 2007, by the Ethics Committee in Animal Experimentation at the State University of Londrina (UEL) in Brazil. The study was registered under no. 58/06.

\section{Acknowledgments}

We are grateful for all facilities provided by Doctor Margarida Collares-Pereira that made possible the realization of part of this work in the Lab of Leptospirosis and Lyme Borreliosis at the Institute of Hygiene and Tropical Medicine, Lisbon, Portugal.

This work was supported by CAPES - Coordination for Improvement of Higher Level Personnel.

\section{References}

Anderson JF (1988) Mammalian and avian reservoirs for Borrelia burgdorferi. Ann N Y Acad Sci 539:180-191.

Aragão HB, Fonseca F (1961) Notas de Ixodologia, VIII. Lista e chave para os representantes da fauna ixodológica brasileira. Mem Inst Oswaldo Cruz 59:115-129.

Ataliba AC (2006) Estudo de Borrelia spp. no Brasil. São Paulo, Brasil, 63 pp (M.Sc. Dissertation. Faculdade de Medicina Veterinária e Zootecnia. FMVZ).

Azulay RD, Abulafia L, Sodre CS, Azulay RA, Azulay MM (1991) Lyme disease in Rio de Janeiro. Brazil In J Dermatol 30:569-571.

Baptista S, Quaresma, A, Aires T, Kurtenbach K, Santos-Reis M, Nicholson M, Collares-Pereira M (2004) Lyme borreliosis spirochetes in questing ticks from mainland Portugal. Int J Med Microbiol 293:109-116.
Baranton G, Gerald S, George T, Postic D, Dykhuizen D (2001) Distinct levels of genetic diversity of Borrelia burgdorferi are associated with different aspects of pathogenicity. Res Microbiol 152:149-156.

Barros-Battesti DM, Arzua M, Bechara GH (2006) Carrapatos de importância médico-veterinária da região neotropical: um guia ilustrado para identificação de espécies. São Paulo Vox; ICTTD-3; Butantã.

Basta J, Hulínská D (1999) Sensitivity and inhibition of single-step PCR detection of Borrelia burgdorferi sensu lato in the Presence of Tick DNA. Med Vet Entom (in press)

Bessetti J (2007) An Introduction to PCR Inhibitors. Profiles in DNA. Promega Corporation. http://www.promega.com/ profiles/1001/ProfilesinDNA_1001_09.pdf.

Clark KL, Oliver Jr JH, Grego JM, James AM, Durden LA, Banks CA (2001) Host associations of ticks parasitizing rodents at Borrelia burgdorferi-enzootic sites in South Carolina. J Parasitol 87:1379-1386.

Ciceroni L, Bartoloni A, Ciarrocchi S, Pinto A, Guglielmetti P, Valdez Vasquez C, Gamboa Barahona H, Roselli M, Paradisi F (1997) Serologic survey for antibodies to Borrelia burgdorferi in sheep, goats and dogs in Cordillera Province, Bolivia. Zentralbl Veterinarmed 44:133-137.

Costa IP, Bonoldi VLN, Yoshinari NH (2001) Perfil clínico e laboratorial da Doença de Lyme-símile no Estado de Mato Grosso do Sul: análise de 16 pacientes. Rev Bras Reumatol 41:142-150.

Couceiro S, Baptista S, Franca I, Gonçalves L, Vieira ML, Collares-Pereira M (2003) Cultura vs PCR: que apoio diagnóstico de Borreliose de Lyme. Acta Reumatol Port 28:77-82.

Dantas-Torres F (2008) Canine vector-borne diseases in Brazil. Parasit Vectors 1:25.

De Michelis S, Sewell HS, Collares-Pereira M, Santos-Reis M, Schouls LM, Benes V, Holmes EC, Kurtenbach K (2000) Genetic Diversity of Borrelia burgdorferi sensu lato in ticks from Mainland Portugal. J Clin Microbiol 38:2128-2133.

Durden LA, Olivier Jr JH, Kinsey AA (2001) Ticks (Acari: Ixodidae) and Spirochetes (Spirochaetaceae: Spirochaetales) recovered from birds on a Georgia Island. J Med Entomol 38:231-236.

Fernández-Soto P, Pérez-Sánchez R, Alamo-Sanz R, EncinasGrandes A (2006) Spotted fever group rickettsiae in ticks feeding on humans in northwestern Spain: is Rickettsia conorii vanishing? Ann N Y Acad Sci 1078:331-333.

Figueiredo LTM, Badra SJ, Pereira LE, Szabó MPJ (1999) Relato sobre carrapatos coletados no sudeste e centro-oeste do Brasil analisando o potencial transmissão de microorganismos para o homem. Rev Soc Bras Med Trop 32:613-619.

Fonseca AH, Salles RS, Salles SAN, Madureira RC, Yoshinari NH (2005) Borreliose de Lyme simile: uma doença emergente e relevante para a dermatologia no Brasil. An Bras Dermatol 80:171-178.

Fonseca AH, Soares CO, Cruz FCM, Yoshinari NH (1994) Doença de Lyme em bovinos e caninos no estado do Rio de Janeiro. XXIII Congresso Brasileiro de Medicina Veterinária, Recife, Pernambuco, pp 123.

Galo KR (2006) Frequência de anticorpos anti-Borrelia burgdorferi em equinos na mesorregião metropolitana de Belém, Estado do Pará. Pará, Brasil, 48 pp (M.Sc. Dissertation. Universidade Federal do Pará). 
Gaumond G, Tyropolis A, Grodzicki S, Bushmich S (2006) Comparison of direct fluorescent antibody staining and real-time polymerase chain reaction for the detection of Borrelia burgdorferi in Ixodes scapularis ticks. J Vet Diag Invest 18:583-586.

Gonzalo OA (2001) Búsqueda de la espiroqueta Borrelia burgdorferi sensu lato mediante PCR en garrapatas ixoideas chilenas silvestres / Search for the spirochete Borrelia burgdorferi sensu lato by polymerase chain reaction in Chilean ticks. Rev Med Chile 129:270-276.

Guglielmone AA, Aguirre DH, Mangold AJ, Gaido AB (1987) Borrelia sp en Boophilus microplus, la garrapata comun del ganado vacuno, en Tucuman, Argentina. Vet Argentina 4:248-249.

Guglielmone AA, Beati L, Barros-Battesti DM, Labruna MB, Nava S, Venzal JM, Mangold AJ, Szabó MP, Martins JR, González-Acuña D, Estrada-Peña A (2006) Ticks (Ixodidae) on humans in South America. Exp Appl Acarol 40:83-100.

Guy EC, Stanek G (1991) Detection of Borrelia burgdorferi in patients with Lyme disease by polymerase chain-reaction. J Clin Pathol 44:610-611.

Hiraoka H, Shimada Y, Sakata Y, Watanabe M, Itamoto K, Okuda M, Masuzawa T, Inokuma H (2007) Detection of Borrelia garinii, Borrelia tanukii and Borrelia sp. closely related to Borrelia valaisiana in ixodes ticks removed from dogs and cats in Japan. Vet Parasitol 144:188-192.

Jongejan F, Uilenberg G (2004) The global importance of ticks. Parasitol 129:3-14.

Kurtenbach K, Sewell HS, Ogden NH, Randolph SE, Nuttall PA (1998) Serum complements sensitivity as a key factor in Lyme disease ecology. Infec and Immunity 66:1248-1251.

Madureira RC (2007) Sorologia para Borrelia burgdorferi em equinos do estado do Pará e caracterização genotípica de isolados de Borrelia spp. Rio de Janeiro, Brasil, 89 pp (Ph.D Thesis. Universidade Federal Rural do Rio de Janeiro).

Martins JR, Correa BL, Cereser VH, Smith RD (1996) Borrelia theileri: observação em carrapatos do gênero Boophilus microplus no município de Guaíba, RS, Brasil. Ciênc Rural 26447-450.

Martins TF, Spolidorio MG, Batista TCA, Oleira IAS, Yoshinari NH, Labruna MB (2009) Ocorrência de carrapatos (Acari: Ixodidae) no município de Goiatins, Tocantins. Rev Bras Parasitol Vet 18:50-52.
Neumann LG (1899) Revision de la famille des ixodides ( $3^{\mathrm{a}}$ mémorie). Mem Soc Zool France 12:107-294.

Palácios R, Osorio LE, Giraldo LE, Torres AJ, Philipp MT, Ochoa MT (1999). Positive IgG Western Blot for Borrelia burgdorferi in Colombia. Mem Inst Oswaldo Cruz 94:499503.

Rijpkema AGT, Molkenboer MJCH, Schouls LM, Jongejan F, Schellenkens JFP (1995) Simultaneous detection and genotyping of three genomic groups of Borrelia burgdorferi sensu lato in Dutch Ixodes ricinus ticks by characterization of the ampliefed intergenic spacer region between $5 \mathrm{~S}$ and 23S rRNA genes. J Clin Microbiol 33:3091-3095.

Salles RS, Fonseca AH, Scofield A, Madureira RC, Yoshinari NH (2002) Sorologia para Borrelia burgdorferi latu sensu em equinos no estado do Rio de Janeiro. A hora veterinária 127:46-49.

Soares CO, Ishikawa MM, Fonseca AH, Yoshinari HH (2000) Borrelioses, agentes e vetores. Pesq Vet Brasil 20:1-19.

Sparagano OAE, Allsopp MTEP, Mank RA, Rijpkema SGT, Figueroa JV, Jongejan F (1999) Molecular detection of pathogen DNA in ticks (Acari: Ixodidae): A review. Exp. App Acarol 23:929-960.

Talhari S, Talhari AC, Ferreira LCL (1992) Eritema cronicum migrans, eritema migratorio, doença de Lyme ou borreliose de Lyme. An Bras Dermatol 67:205-209.

Yoshinari NH, Oyafuso LK, Monteiro FG, Barros PJ, Cruz FC, Ferreira LG, Bonasser F, Baggio D, Cossermelli W (1993a) Lyme disease. Report of a case observed in Brazil. Rev Hosp Clin Fac Med São Paulo 48:170-174.

Yoshinari NH, Steere AC, Barros PJL, Cruz FCM, Mendonça M, Oyafuso LK, Levy L, Cossermelli W (1993b) Lyme disease in Brazil: report of five cases. Rev Esp Reumatol 20(Supl.1):156.

Yoshinari NH, Barros PJL, Fonseca AH, Bonoldi VLN, BarrosBattesti DM, Schumaker TTS, Cossermelli W (1995) Borreliose de Lyme zoonose emergente de interesse multidisciplinar. Newslab 12:90-104.

Yoshinari NH, Barros PJL, Bonoldi VLN, Ishikawa M, Battesti DMB, Pirana S, Fonseca AH, Schumaker TT (1997) Perfil da Borreliose de Lyme no Brasil. Rev Hosp Clin Fac Med São Paulo 52:111-117.

All the content of the journal, except where otherwise noted, is licensed under a Creative Commons License CC BY-NC. 